(6) OPEN ACCESS

${ }^{1}$ Center for Health Law, Ethics and Human Rights, Boston University School of Public Health, Boston, Massachusetts, USA

${ }^{2}$ Department of Medicine, Boston University School of Medicine, Boston, Massachusetts, USA

Correspondence to Dr George J Annas, Center for Health Law, Ethics and Human Rights, Boston University School of Public Health, Boston, MA 02118,USA; annasgj@bu.edu

Received 6 September 2018 Revised 11 December 2018 Accepted 12 December 2018 Published Online First 24 January 2019

Check for updates

(C) Author(s) (or their employer(s)) 2019. Re-use permitted under CC BY-NC. No commercial re-use. See rights and permissions. Published by BMJ.

To cite: Annas GJ, Crosby S. $J$ R Army Med Corps

2019:165:303-306.

\title{
US military medical ethics in the War on Terror
}

\author{
George J Annas, ${ }^{1}$ S Crosby ${ }^{1,2}$
}

\section{ABSTRACT}

Military medical ethics has been challenged by the post-11 September 2001 'War on Terror'. Two recurrent questions are whether military physicians are officers first or physicians first, and whether military physicians need a separate code of ethics. In this article, we focus on how the War on Terror has affected the way we have addressed these questions since 2001. Two examples frame this discussion: the use of military physicians to force-feed hunger strikers held in Guantanamo Bay prison camp, and the uncertain fate of the Department of Defense's report on 'Ethical Guidelines and Practices for US Military Medical Professionals'.

Secretary of Defense Jim Mattis wrote to all members of the Department of Defense (DoD) in 2017 with the subject line, 'Ethical Standards for All Hands'. ${ }^{1}$ The core of his message:

I expect every member of the Department to play the ethical midfield. I need you to be aggressive and show initiative without running the ethical sidelines, where even one misstep will have you out of bounds. I want our focus to be on the essence of ethical conduct: doing what is right at all times, regardless of the circumstances or whether anyone is watching. (Emphasis added)

The Secretary's admonishment was in sharp contrast to that of General Michael Hayden, former director of the National Security Agency, and the Central Intelligence Agency, who told his agents after the 9/11 attacks: I want you to play the entire [ethics] field to the limits, 'I want to see chalk dust on [your] cleats.' ${ }^{2}$ Mattis also expressed the need for training in ethical dilemma resolution, as well as knowing what it means to live by 'an ethical code', and follow the military's Oath of Office. The Mattis letter treats all military and civilian personnel in the DoD the same, and holds all of them to the same ethics standard. His message has been widely praised. Nevertheless, for physicians (and other healthcare professionals) serving in the US military, it begs at least two persistent questions: (1) Are physicians in the US military physicians first or officers first? and (2) Should military medical ethics be spelled out in a separate code?

The question of whether the US military itself needs new standards of ethics has been raised periodically since World War II. For example, in 1955 President Dwight D Eisenhower issued a new 'Code of Conduct for Members of the Armed Forces of the United States', in reaction to the 'brainwashing' of American prisoners of war during the Korean conflict. $^{3}$ One of the few pre-9/11 medical ethics disputes involved the plan to provide US troops in the first Gulf War with experimental drugs and
Key messages

The post-9/11 "war on terror" has deformed military medical ethics in the US.

- The US military has explicitly rejected the WMA's ethical rules regarding hunger strikers in detention.

- The US should re-establish medical ethics rules that explicitly permit military physicians to put the interests of their patients first.

vaccines without their consent in the event of a chemical or biological attack. ${ }^{4}$ But mostly military medical ethics became the subject of intense discussion only after $9 / 11$. The baseline for military medical ethics was set by the coincidental publication by the US military of a 2-volume set, Military Medical Ethics, in 2003, which remains the most authoritative US publication on this subject. ${ }^{5}$

In this article we focus on two specific topics to illuminate the 'physician first problem', and arguments for and against developing a separate medical ethics code for military physicians. The first example is the most publicly discussed military medical ethics controversy of the past 15 years, the use of military physicians to force-feed hunger strikers in Guantanamo Bay. ${ }^{6}$ The second is one of the least publicly discussed ethics reports (whose future is still uncertain), the Defense Health Board's 2015 report on 'Ethical Guidelines and Practices for US Military Medical Professionals'?

\section{PRISON HUNGER STRIKES AND MEDICAL ETHICS}

The War on Terror incited a vigorous response that could not be held in check by existing ethics codes. After 9/11, there were scandals at Abu Ghraib, abuses at Bagram Air Base in Afghanistan and reports that psychologists at Guantanamo Bay prison were participating in interrogations. In response, the Assistant Secretary of Defense for Health Affairs, William Winkenwerder, decided to consolidate all 'principles and procedures for US military medical personnel when working with detainees under control of US armed forces.' When the principles were announced, in 2006, the most controversial proved to be the role of military physicians in force-feeding competent hunger strikers at Guantanamo. The new Instruction was entitled 'Medical Program Support for Detainee Operations' and the hunger strike section provided that,

In the case of a hunger strike, attempted suicide, or other attempted serious self-harm, medical treatment or intervention may be directed without the consent 
of the detainee to prevent death or serious harm. Such action must be based on a medical determination that immediate treatment or intervention is necessary to prevent death or serious harm, and, in addition, must be approved by the commanding officer of the detention facility... ${ }^{8}$ (Section 4.7.1, emphasis added)

This provision is confusing at best. Competent hunger strikers are engaged in a protest, they are neither suicidal nor mentally ill. Lumping them into these latter two categories seems designed to justify some sort of forced treatment, here forced feeding. But this directly contravenes the World Medical Association's (WMA) Declaration of Malta which prohibits physicians from force-feeding competent hunger strikers. ${ }^{9}$ This matters because to the best of our knowledge, this is the only time US military medical ethics standards have been adopted that explicitly permit physicians in the military to act in a manner that contravenes applicable worldwide medical ethics standards. ${ }^{10}$

In a 7 June 2006 press conference on the new Instruction, Winkenwerder acknowledged this conflict, but sought to downplay its importance, saying: 'We have a policy that is to preserve life. That policy is an ethical policy. It's in the best interests of the individual who is a hunger striker, for his life to be preserved...' On medical ethics specifically, Winkenwerder said:

We view what we are doing as largely consistent with [the Malta] declaration... Malta permits feeding when the hunger striker has lapsed into a coma and is impaired and unable to make a decision. It's our view that we're basically along the same ethical tenets, same ethical line of thinking, we just don't want to have someone get to death or near death before we seek to save them. And that only makes good sense. ${ }^{11}$

Winkenwerder was able to argue that his new policy was following the 'spirit' of Malta because the 1992 version of Malta, still in effect in the summer of 2006, arguably left a large degree of discretion in the hands of physicians. To eliminate any ambiguity, the WMA amended its Declaration of Malta in the fall of 2006 to explicitly always prohibit force-feeding of a competent hunger striker: 'Forcible feeding is never ethically acceptable. Even if intended to benefit, feeding accompanied by threats, coercion, force or use of physical restraints is a form of inhuman and degrading treatment.' The 2017 version, which includes new details on the use of advance directives, retains this absolute prohibition.

A 2009 report on Guantanamo, commissioned by President Barack Obama and led by Admiral Patrick Walsh, concedes that the military physicians at Guantanamo do not follow the Declaration of Malta. Instead, the report references the 2006 Instruction and the US Bureau of Prisons regulations. Both of these documents permit force-feeding to prevent selfharm. The report concedes that military physicians cannot both force-feed competent hunger strikers and simultaneously follow medical ethics. Nonetheless, the report makes no attempt to determine when, if ever, military physicians need not follow basic principles of medical ethics (eg, respect for patient autonomy). ${ }^{12}$

The constitutionality of force-feeding at Guantanamo did not get a full hearing in a US federal court until 2014. The courts generally try not to get involved in military affairs, even those involving non-consensual experimentation on service personnel. Nonetheless, sometimes they have little choice, and this is one of them. Judge Gladys Kessler was asked to prohibit the forced cell extraction followed by forced feeding in a restraint chair of Abu Wa'el Dhiab. Dhiab had been a prisoner at Guantanamo for 12 years, was never charged with a crime and was cleared for release in 2009. Judge Kessler initially ruled that all forced cell extractions and force-feeding must end, the first time such an order had been issued in the history of force-feeding at Guantanamo. The case, however, was complex: Dhiab was not opposed to voluntary enteral feeding at the hospital, only to being force-fed in a painful manner in a restraint chair. The DoD remarkably refused this request. Judge Kessler described the DoD's refusal as presenting her with an anguishing Hobson's choice: to reissue another temporary restraining order against force-feeding 'despite the very real probability that $\mathrm{Mr}$ Dhiab will die... or allow medical actions to keep Mr Dhiab alive, but at the possible cost of great pain and suffering.' She decided to permit the physicians at Guantanamo to resume force-feeding because she did not believe she had the authority to prohibit it. ${ }^{13}$ An appeals court later ruled that she did in fact have oversight authority. ${ }^{14}$

Dhiab's case illustrates many of the elements that are wrong with the Guantanamo force-feeding regime, and why it conflicts with basic medical ethics: (1) the prisoner is competent and should have the right to refuse treatment; (2) forced feeding can be ordered by a non-medical person (the base commander) usually long before the prisoner is in any medical danger from his hunger strike; (3) the prisoner is brought to the restraint chair violently, by forced cell extraction; (4) nasogastric feeding takes place in up to 8-point restraints (feet, wrists, chest, shoulders and sometimes head) in a 'restraint chair'; and (5) this method of force-feeding violates Malta and Common Article 3 of the Geneva Conventions which prohibits cruel, inhuman and degrading treatment. ${ }^{15}$

The cruelty of this method would be apparent to anyone seeing the videotapes of the forced cell extractions and the restraint chair nasogastric feedings. Judge Kessler ordered these videotapes be made public, but ultimately an appeals court ruled that the DoD need not release them, because they could be used in terrorist 'propaganda and in carrying out attacks on Americans'. Before Judge Kessler could hold another hearing on Dhiab's treatment, Dhiab, a Syrian, was released to Uruguay, where he had no family or friends. He is no longer in Uruguay, but his current whereabouts is unknown.

As of this writing, Guantanamo physicians continue to be governed by the 2006 Instruction, and continue to force-feed hunger strikers in restraint chairs, although there have been a series of standard operating procedures issued to govern forcefeeding at Guantanamo, and the issue remains the single most controversial military medical ethics issue in our post-9/11 War on Terror. ${ }^{16}$

\section{THE HEALTH ETHICS BOARD REPORT}

In May 2011, the Assistant Secretary of Defense for Health, Jonathan Woodson, asked that the Defense Health Board be tasked with reviewing 'military medical professional practice policies and guidelines'. Two questions were to be addressed: (1) 'How can military medical professionals most appropriately balance their obligations to their patients against their obligations as military officers?' and (2) 'How much latitude should military medical professionals be given to refuse participation in medical procedures... with which they have ethical reservations or disagreement?' The Defense Health Board, chaired by former American Medical Association (AMA) president Nancy Dickey, delegated the assignment to its Medical Ethics Subcommittee which, under the leadership of Adil Shamoo, began meeting in August 2013. Its final report, 
'Ethical Guidelines and Practices for US Military Medical Professionals', was adopted by the Defense Health Board and released in March 2015. The report is a solid piece of work, and we, among others, urged the DoD to adopt it quickly.

In June, 2015, we (together with Gerald Thomson, former Dean of Columbia University School of Medicine) wrote then Secretary of Defense Ashton Carter to request a meeting with him to discuss the report. ${ }^{17}$ In our letter, we highlighted what we still think is the most important conclusion of the report, recommendation 2: 'Throughout its policies, guidance, and instructions, DoD must ensure that the military bealth care professional's first ethical obligation is to the patient.' We argued, 'This is really all that has to be said about medical ethics [in the military] and all that should be said.' This statement, however, is a gross oversimplification: much more does need to be said.

First, the report recommended the creation of a new explicit code of ethics for healthcare professionals in the military. In view of the confusion illustrated in the force-feeding of military prisoners, this seems reasonable. On the other hand, we believe that medical ethics is not employment bound, but universal. In this context, an additional code that says any more than that 'the military physician's first ethical obligation is to the patient' could add more confusion than illumination. Nonetheless, military physicians are likely to run into at least some circumstances that they would never face outside of the military, and it is sensible to have more specific ethical guidance for these challenges, although not a separate general code of ethics. The report's recommendation 3, that commanders 'should excuse health professionals from performing medical procedures that violate their professional codes of ethics...' we think is especially useful in this context. This is because it is the non-medical commanders, who are unlikely to appreciate the role of medical ethics in a physician's life, are most likely to ask military physicians to violate medical ethics. Accordingly, educating commanders about medical ethics may be more effective than further educating military physicians. It is also worth underlining that when commanders order military physicians to act outside the realm of medical ethics, it is not that the physician experiences 'divided loyalty'. Rather it is more accurate to describe the commander as engaging in 'dual use' of military physicians: for example, as in Guantanamo, using physicians as physicians and as part of the prison's guard force or interrogation team. ${ }^{18} 19$

Finally our letter emphasised what the report mentioned only in passing, the elephant in the room (the continuing force-feeding of hunger strikers at Guantanamo). This was, we believe, the primary reason for doing the report at all. In our words, 'The most critical area of failure of military medical ethics has been in responding to hunger strikes, and if we expect our military physicians and health care professionals to follow medical ethics, we must put a system in place that not only permits ethical behavior, but supports it.' Such a system is not suggested in the report, but it should be developed. 'Ethics, even explicit patient-centered ethics, without a well-developed and understood implementation strategy, will only be window-dressing.' Woodson responded to our letter almost immediately, writing, the Department is reviewing the report 'carefully and methodically...,20

A few months later, on 7 October 2015, we wrote another letter to Secretary Carter, this one joined by a who's who of leading civilian physicians, including past presidents of the American Psychiatry Association, the American College of Physicians, the WMA and the AMA. ${ }^{21}$ This letter emphasised much more strongly that the 'critical issue largely absent' from the report is the post-9/11 treatment of War on Terror suspects and wartime detainees, saying: 'We are deeply troubled by the absence of specific, substantial information and detailed recommendations that speak to the national security detention context-recommendations that address an era of abuse that has now been studied, documented, and widely publicized, including by Congress.' The letter writers noted with approval that the report would outlaw the force-feeding of Mr Dhiab, discussed earlier. Most importantly, the letter writers suggested DoD actively support a series of specific ethical principles, regarding national security detention, including:

Physicians should not be involved in abusive practices, including participating in, being present for, condoning or facilitating torture or cruel, inhuman or degrading treatment.

Physicians should not be directly involved in interrogation, including conducting, participating in, or monitoring interrogation.

Physicians must maintain the confidentiality of medical information and not provide medical information for use in torture, cruel, inhuman or degrading treatment, or any interrogation.

Physicians must not treat prisoners for the purpose of returning them to interrogation; torture; or cruel, inhuman or degrading treatment.

Physicians must report torture, abuse, or coercive treatments including those related to interrogation.

Physicians must have clinical independence in treating detainees.

A few months later, in December 2015, we got a response to the 7 October letter from Woodson (who requested the report). ${ }^{22}$ Woodson assured us that the report was being reviewed by the Department's new 'Medical Ethics Integrated Product Team', and that its findings are due to him by the end of the year (2015), and 'I will carefully consider them before I develop my plan of action.' That was almost 3 years ago. Woodson has retired from his job at the Pentagon and returned to academia (at Boston University), and no follow-up has been reported.

In May 2016, the Chair of the Subcommittee, Adil Shamoo, wrote an essay for the Hastings Center which he entitled 'US Military Medical Ethics Guidelines in Limbo', ${ }^{23}$ and limbo seems to be where they currently reside. They are not perfect, but they nonetheless are helpful and should be adopted. Shamoo's bottom line needs to be emphasised not just by the Assistant Secretary for Medical Affairs, but by Secretary Mattis as well: 'Health care professionals should have the freedom to follow their conscience and their professional association's code of ethics during their service in the military.' This position also answers both of the questions we began with: military physicians should always be free to follow universal medical ethics, and no separate 'military' medical ethics code is needed.

\section{CONCLUSION}

It seems reasonable to conclude that medical ethics in the US military has been deeply compromised by the reaction of the US civilian and military leaders to the 9/11 attacks. The continuing controversy, both in the US military and in the US courts, involving rules for the force-feeding of military prisoners, seems incapable of resolution in the context of our continuing 'War on Terror'. As long as preventing 'another 9/11' is seen as more important than following principles of medical ethics, the US military will not be able to move beyond its post-9/11 antiterrorist ethics. The future should be one in which military physicians never question that they are physicians first, bound by universal medical ethics. Under 
this precept, force-feeding of competent hunger strikers by physicians is categorically prohibited. The Shamoo Ethics report should be officially adopted along with the institutional support required for its implementation. This could be at least one good thing that comes out of the War on Terror.

Correction notice This article has been corrected since it was published Online First. The article was made Open Access and copyright licence updated to CC-BY-NC. A disclaimer was also added to the article.

Contributors The authors contributed equally in the preparation of this manuscript.

Funding The authors have not declared a specific grant for this research from any funding agency in the public, commercial or not-for-profit sectors.

Disclaimer The views expressed in this article are those of the authors and do not reflect the official policy or position of the US Department of Defense or the US Government.

Competing interests None declared.

Patient consent Not required.

Provenance and peer review Not commissioned; externally peer reviewed.

Open access This is an open access article distributed in accordance with the Creative Commons Attribution Non Commercial (CC BY-NC 4.0) license, which permits others to distribute, remix, adapt, build upon this work non-commercially, and license their derivative works on different terms, provided the original work is properly cited, appropriate credit is given, any changes made indicated, and the use is non-commercial. See: http://creativecommons.org/licenses/by-nc/4.0/.

\section{REFERENCES}

1 Jim Mattis letter of August 17. 2017. Available: https://dod.defense.gov/./1/./EthicalStandards-for-All-Hands-SecDef-04-Aug-17

2 Hayden M. Playing the edge: American Intelligence in the Age of Terror 2016.

3 Eisenhower PDD. Executive order 10631, Auf. 171955.
4 Annas GJ. Protecting soldiers from friendly fire: the consent requirement for using investigational drugs and vaccines in combat. Am I Law Med 1998;24:245-60.

5 Ethics MM. Military medical ethics (Beam TE, Sparacino LR, eds) 2 vol., USUHS, Bethesda,MD, 2003. N Engl J Med 2005;352:312-4.

6 Annas GJ. Worst case bioethics: death, disaster, and public health. New York: Oxford U. Press, 2010: 59-74.

7 2019. Available: https://goo.gl/JBgs7Z

8 DoD instruction, medical program support for detainee operations, No. 23120.08E, June 6. 2006.

9 World Medical Association. Declaration of Malta on Hunger Strikes, adopted Nov. 1991. Available: https://www.wma.net/policies-post/wma-declaration-of-malta-onhunger-strikers

10 Institute of medicine, military medical ethics: issues regarding dual loyalties. Washington, DC: Academies Press, 2009.

11 June 7, 2006 Winkenwerder Press conference (transcript has been removed from the internet; copy available from the authors).

12 Rubenstein LS, Annas GJ. Medical ethics at Guantanamo Bay detention centre and in the US military: a time for reform. The Lancet 2009;374:353-5.

13 Savage C. Judge allows force-feeding of detainee at Guantanamo. New York Times, 2014.

14 Savage C. Appeals court allows challenges by detainees at Guantanamo prison. New York Times, 2014

15 Annas GJ, Crosby SS, Glantz LH. Guantanamo Bay: a medical ethics-free zone? N Eng J Med 2013:369:101-3.

16 E.g., Joint Task Force Guantanamo Bay, Joint Medical Group, Medical Management of Detainees on Hunger Strike, SOP: jtf-jmg \#001, March 52013.

17 June 2015 letter on file with authors.

18 Annas GJ. American vertigo: 'dual use',' prison physicians, research, and Guantanamo. Case West Res I International Law 2011;43:631-50.

19 Miller S, Selgelid MJ. Ethics and the dual-use dilemma in the life sciences (in) Allhoff F. In: Allhoff F, ed. Physicians at war: the dual-loyalties challenge. Springer, 2008: 195-211.

20 Letter on file with authors

21 October 7, 2015 Letter on file with authors.

22 December 15, 2015 Letter on file with authors.

23 Shamoo AE. U.S. military medical ethics guidelines in limbo, Hastings Center blog. Available: https://www.thehastingscenter.org/u-s-military-medical-ethics-guidelinesin-limbo/ 